
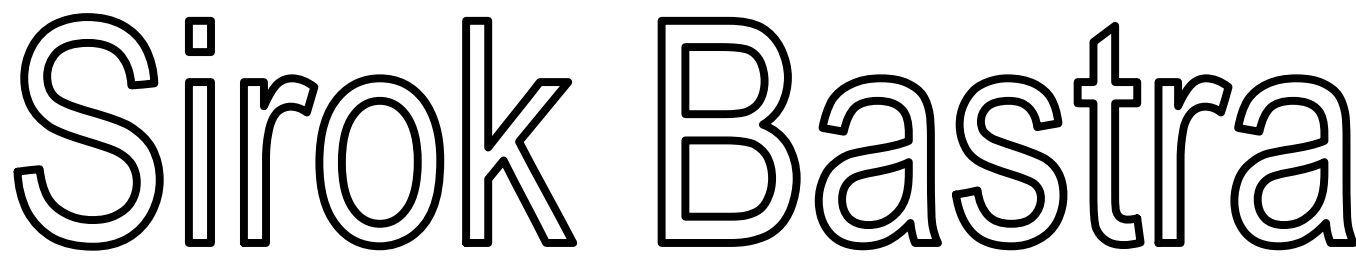

J URNAL ILMIAH KEBAHASAAN DAN KESASTRAAN

\begin{tabular}{|c|c|c|c|c|c|}
\hline $\begin{array}{c}\text { Sirok Bastra } \\
\text { Jurnal Kebahasaan dan } \\
\text { Kesastraan }\end{array}$ & Volume 5 & Nomor 2 & $\begin{array}{c}\text { Hlm. } \\
101-196\end{array}$ & $\begin{array}{c}\text { Pangkalpinang, } \\
\text { Desember } \\
2017\end{array}$ & $\begin{array}{c}\text { ISSN } \\
2354-7200\end{array}$ \\
\hline
\end{tabular}

KANTOR BAHASA KEPULAUAN BANGKA BELITUNG 


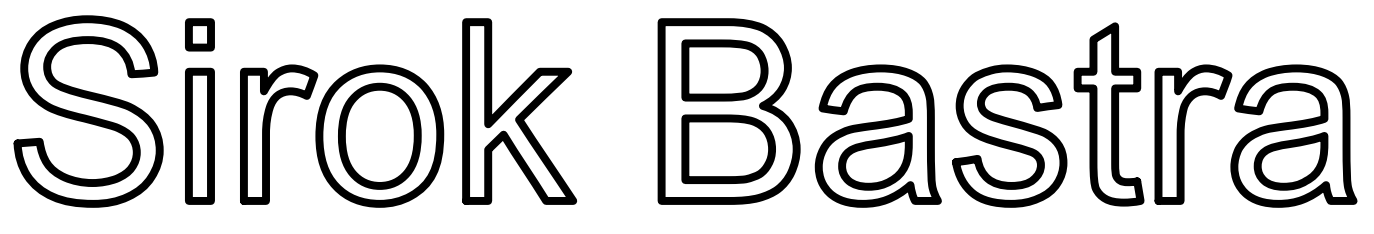

\section{J URNAL ILMIAH KEBAHASAAN DAN KESASTRAAN}

Jurnal ini merupakan wadah informasi kebahasan, kesastraan, dan pengajarannya yang memuat hasil penelitian, studi kepustakaan, dan tulisan ilmiah bidang kebahasan dan kesastraan serta pengajarannya. Sirok Bastra terbit dua kali setahun, yakni Juni dan Desember, serta terbit sejak Juni 2013.

\section{Penanggung Jawab}

Kepala Kantor Bahasa Kepulauan Bangka Belitung

Drs. Hidayatul Astar, M.Hum.

\section{Mitra Bestari}

Prof. Dr. Agus Nuryatin, M.Hum. (Bidang Sastra dan Pengajarannya)

Prof. Amrin Saragih, Ph.D., M.A. (Bidang Bahasa dan Pengajarannya)

Dr. Felicia Nuradi Utorodewo, M.Hum. (Bidang Bahasa dan Pengajarannya)

Dr. Pujiharto, M.Hum. (Bidang Sastra dan Pengajarannya)

\section{Pemimpin Redaksi}

Rahmat Muhidin, S.S.

\section{Penyunting}

Dr. Asyraf Suryadin, M.Pd.

Prima Hariyanto, S.Hum.

Sarman, S.Pd.

\section{Perancang Sampul}

Feri Pristiawan, S.S.

\section{Pengatak}

Dewi Septi Kurniawati, S.Kom.

\section{Kesekretariatan \\ Ria Anggraini, S.E. Juliati, S.E.}

\section{Alamat Redaksi dan Penerbit}

Kantor Bahasa Kepulauan Bangka Belitung

Jalan Letkol Saleh Ode No. 412, Kota Pangkalpinang, Prov. Kepulauan Bangka Belitung Telepon (0717) 438455, Faksimile(0717)9103317, Pos-el: sirokbastra@gmail.com, sirokbastra@kemdikbud.go.id

Pemuatan suatu tulisan dalam jurnal ini tidak berarti redaksi menyetujui isi tulisan tersebut. Isi tulisan menjadi tanggung jawab penulis. Tulisan telah ditinjau dan diulas oleh mitra bestari. Setiap karangan dalam jurnal ini dapat diperbanyak setelah mendapat izin tertulis dari penulis, redaksi, dan penerbit. 


\section{PENGANTAR}

Puji syukur ke hadirat Pemilik dan Pencipta semesta ini yang memiliki kuasa atas diri-Nya sendiri. Dialah Tuhan Yang Maha Esa yang telah memberikan rahmat dan hidayah-Nya sehingga Volume 5 Nomor 2 Jurnal Sirok Bastra Tahun 2017 dapat terbit tepat pada waktunya.

Pada edisi ini dimuat sepuluh tulisan, yakni lima tulisan kebahasaan, empat tulisan kesastraan, dan satu tulisan pengajaran sastra.

Dalam penelitiannya, Hotnida Novita Sary menganalisis iklan komersial Meikarta yang telah membuat perusahaan tersebut berhasil mencatatkan penjualan yang fantastis. Penelitian yang dilakukannya menggunakan pisau bedah analisis wacana kritis Fairclough (1989). Iklan Meikarta membandingkan kesuperioritasan mereka dibandingkan kota metropolitan lain, seperti Jakarta. Meikarta juga menanamkan ideologi bagi masyarakat kota besar bahwa kota metropolitan saat ini sudah tidak aman, kotor, dan macet.

Dalam makalahnya, Hidayatul Astar mengkaji realisasi konsep bahasa Indonesia ke dalam bahasa Rejang. Menurutnya, masyarakat Rejang tidak memiliki konsep (kata atau istilah) yang cukup untuk mewakili pikiran dan perasaan tertentu ketika berkomunikasi, terutama yang terkait dengan konsep kehidupan modern atau yang sesuai dengan perkembangan zaman. Karena itu, bahasa Rejang perlu memungut atau mengambil dari bahasa lain, khususnya dari bahasa Indonesia. Realisasi bentuk konsep yang ditemukan adalah realisasi tanpa perubahan dan realisasi dengan perubahan. Berdasarkan data, realisasi perubahan dalam sebuah konsep dapat satu kali atau lebih. Realisasi perubahan itu berupa penghilangan, penggantian, dan penambahan bunyi vokal atau konsonan tertentu pada posisi tertentu. Terjadinya perubahan realisasi bunyi bahasa Indonsia ke dalam bahasa Rejang disebabkan oleh keinginan penutur bahasa Rejang dan adaptasi terhadap bunyi yang sudah ada.

Dalam kajiannya, Mardi Nugroho membahas pembentukan kata dalam bahasa Talondo di Sulawesi Barat. Hasil analisis data menunjukkan bahwa ada tiga macam cara pembentukan kata dalam bahasa Talondo, yaitu afiksasi, reduplikasi, dan pemajemukan. Pembentukan kata dengan afiksasi terdiri atas pembentukan kata dengan prefiksasi, konfiksasi, infiksasi, dan sufiksasi. Pembentukan kata dengan reduplikasi terdiri atas reduplikasi murni, reduplikasi sebagian, dan reduplikasi yang berkombinasi dengan afiksasi.

Dalam kajiannya, Muhammad Fadely membahas makna dan bentuk pemakaian eufemisme dan disfemisme dalam feature karya Ruslan Ismail Mage yang bermanfaat bagi pengajaran bahasa Indonesia dan pengembangan bahasa di media massa cetak. Hasil analisis menunjukkan bahwa pemakaian eufemisme lebih banyak daripada pemakaian disfemisme. Berdasarkan simpulan tersebut, peneliti menyarankan bahwa dalam menyampaikan suatu informasi kepada khalayak umum hindari tulisan-tulisan yang dapat mengaburkan dan tidak terus terang demi maksud-maksud tertentu.

Dalam kajiannya, Asri Soraya Afsari membahas karakteristik bahasa yang digunakan dalam iklan komersial ponsel yang berada di Kota Bandung. Hasil penelitian menunjukkan bahwa bentuk dan fungsi bahasa yang digunakan dalam iklan ponsel di Kota Bandung berupa penulisan huruf kapital secara keseluruhan dan penulisan huruf kapital pada awal kata. Bahasa iklan ponsel memiliki fungsi informatif dan konatif (persuatif).

Dalam tulisannya, Erwin Wibowo mendeskripsikan makna semiotik budaya Lampung yang ada di dalam antologi Kitab Cerpen Perempuan di Rumah Panggung. Hasil penelitian mengungkapkan ikon, indeks, dan simbol budaya Lampung melalui pendekatan semiotik yang dipakai dalam Kitab Cerpen Perempuan di Rumah Panggung karya Isbedy Stiawan ZS dan memberi deskripsi tentang ikon, indeks, dan simbol tesebut.

Dalam penelitiannya, Prima Hariyanto membahas penokohan dalam Kitab Omong Kosong yang mengambil cerita epos Ramayana. Dalam novel ini, pengarang mengubah pola cerita. Tokoh sentral dalam cerita ini bukan lagi Rama dan Sinta, tetapi Maneka dan Satya. Ceritanya bukan lagi kisah cinta Rama dan Sinta, tetapi kisah perjalanan Maneka dan Satya dalam mencari Kitab Omong Kosong ciptaan Hanoman. Tokoh Rama tidak lagi diceritakan sebagai kesatria yang baik, tetapi sebagai raja yang membawa bencana bagi rakyat di muka bumi.

Dalam kajiannya, Dian Anggraini mengkaji intertekstual lima puisi Indonesia yang berisi tentang sosok wanita yang disebut ibu, yaitu "Ibu Dehulu" (Amir Hamzah), "Ibu” (Chairil Anwar), "Sajak Ibu” (Wiji Thukul), 
"Bunda Air Mata" (Emha Ainun Najib"), dan "Ibu” (K.H. Mustofa Bisri). Hasil telaah itu membuktikan bahwa kelima puisi tersebut merupakan mosaik, kutipan-kutipan, penyerapan, dan perspektif yang beragam terhadap sosok ibu. Setiap penyair mengungkapkan sisi ibu dari pandangan yang berbeda.

Dalam kajiannya, Yuliadi M.R. membahas makna ground dalam cerpen "Uak dan Burung Gagak" dengan pendekatan objektif melalui teori semiotik Pierce. Berdasarkan kajian, terungkap bahwa makna ground dalam cerpen Uak dan Burung Gagak, yaitu ground qualisign berupa warna hitam, sinsign berupa suara koakkoak, dan legisign berupa perilaku mengitari rumah.

Dalam tulisannya, Abdul Azis dan Hajrah membahas dongeng sebagai bahan pembelajaran di sekolah dasar. Data penelitian ini adalah dongeng Cerita Si Jingkiriq, I Kukang, Nenek Pakande, La Dana dan Kerbaunya, dan Puang Tedong. Hasil analisis data dan temuan menunjukkan bahwa rata-rata penilaian responden untuk dongeng sebesar 3,75 (kategori layak dijadikan bahan ajar). Bahan ajar yang dapat digunakan untuk tingkat SD adalah dongeng yang isinya sesuai dengan karakteristik, pengalaman, dan kebutuhan siswa.

Kami mengucapkan terima kasih kepada para penulis yang telah bersedia menerbitkan karya mereka pada edisi ini. Para penulis merupakan peneliti, pakar, dosen, dan mahasiswa dari berbagai perguruan tinggi dan instansi. Terima kasih juga kami sampaikan kepada para mitra bestari kami yang telah memberi ulasan terhadap tulisan-tulisan yang masuk ke redaksi.

Demi memenuhi keberagaman isi dan penulis, Sirok Bastra membuka kesempatan bagi para peneliti dan penulis menyampaikan hasil penelitian dan pemikiran mutakhir dalam bidang kebahasaan, kesastraan, dan pengajarannya. 


\section{UCAPAN TERIMA KASIH UNTUK MITRA BESTARI}

Redaksi Sirok Bastra mengucapkan terima kasih kepada para mitra bestari yang telah meninjau, menimbang, dan mengulas makalah-makalah yang diterbitkan dalam Sirok Bastra Volume 5 Nomor 2, edisi Desember 2017, yakni

Prof. Dr. Agus Nuryatin, M.Hum.

Bidang Sastra dan Pengajarannya

Universitas Negeri Semarang

Semarang, Jawa Tengah

Prof. Amrin Saragih, Ph.D., M.A.

Bidang Bahasa dan Pengajarannya

Universitas Negeri Medan

Medan, Sumatra Utara

Dr. Felicia Nuradi Utorodewo, M.Hum.

Bidang Bahasa dan Pengajarannya

Universitas Indonesia

Depok, Jawa Barat

\section{Dr. Pujiharto, M.Hum.}

Bidang Sastra dan Pengajarannya

Universitas Gadjah Mada

Yogyakarta, Daerah Istimewa Yogyakarta 


\section{DAFTAR ISI}

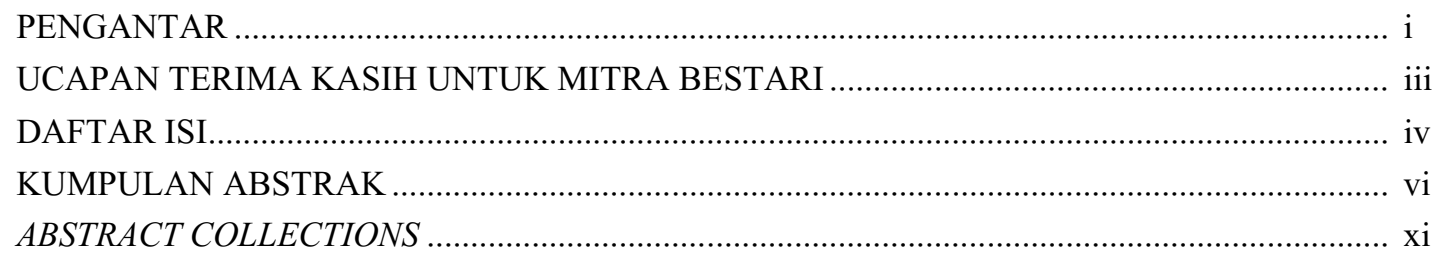

ANALISIS WACANA KRITIS IKLAN KOMERSIAL MEIKARTA

(Critical Discourse Analysis of Meikarta Commercial Advertising)

Hotnida Novita Sary $101-111$

REALISASI KONSEP BAHASA INDONESIA DALAM BAHASA REJANG

(Realization of Indonesian Concept Into Rejang Language)

Hidayatul Astar. $113-121$

PEMBENTUKAN KATA DALAM BAHASA TALONDO

(The Word Formation in Talondo Language)

Mardi Nugroho $123-129$

EUFEMISME DAN DISFEMISME PADA FEATURE-FEATURE KARYA RUSLAN ISMAIL MAGE

(Euphemism and Disphemism in The Features by Ruslan Ismail Mage)

Muhammad Fadely $131-139$

KARAKTERISTIK PENGGUNAAN BAHASA DALAM IKLAN PONSEL DI KOTA BANDUNG

(The Characteristic of Language Usage on Mobile Phone Advertisement in Bandung) Asri Soraya Afsari $141-151$

SIMBOL BUDAYA LAMPUNG DALAM KITAB CERPEN PEREMPUAN DI RUMAH PANGGUNG KARYA ISBEDY STIAWAN Z.S.: KAJIAN SEMIOTIKA

(Lampung Cultural Symbols in Kitab Cerpen Perempuan di Rumah Panggung by Isbedy Stiawan Z.S.: a Semiotic Analysis)

Erwin Wibowo $153-161$

PENOKOHAN DALAM KITAB OMONG KOSONG KARYA SENO GUMIRA AJIDARMA (Characterization in Kitab Omong Kosong by Seno Gumira Ajidarma)

Prima Hariyanto $163-169$

WANITA ISTIMEWA: KAJIAN INTERTEKSTUAL TERHADAP PUISI-PUISI TENTANG IBU

(Special Woman: Intertextual Study of Poems About Mother) 
BURUNG GAGAK SEBUAH TANDA: MAKNA GROUND DALAM CERPEN UAK DAN BURUNG GAGAK

(Brids Crow A Sign: Ground Meaning in Uak and Burung Gagak Short Story)

Yuliadi M.R.

DONGENG SEBAGAI BAHAN PEMBELAJARAN BAHASA INDONESIA DI SEKOLAH

DASAR

(Folktale as Indonesian Language Learning Material in Elementary School)

Abdul Azis dan Hajrah

$191-196$ 
Prima Hariyanto: Penokohan dalam Kitab Omong Kosong Karya Seno Gumira Ajidarma

\title{
PENOKOHAN DALAM KITAB OMONG KOSONG KARYA SENO GUMIRA AJIDARMA
}

\author{
Characterization in Kitab Omong Kosong by Seno Gumira Ajidarma
}

\author{
Prima Hariyanto \\ Kantor Bahasa Kepulauan Bangka Belitung \\ Jalan Letkol Saleh Ode 412, Pangkalpinang \\ Pos-el: patriyawhura@gmail.com
}

(diterima 18 Juli 2017, disetujui 8 September 2017, revisi terakhir 11 Desember 2017)

\begin{abstract}
Abstrak
Pada umumnya, hal yang menonjol dalam wayang adalah tokoh-tokohnya. Karakter tokoh berkaitan dengan lakon dalam kisah tersebut. Oleh karena itu, jika orang melihat sebuah pertunjukan wayang, sebenarnya yang dilihat adalah pertunjukan lakon.Seiring dengan perkembangan zaman, cerita wayang banyak diadaptasi menjadi prosa, puisi, maupun drama modern. Salah satu karya yang mengambil cerita Ramayana adalah Kitab Omong Kosong karya Seno Gumira Ajidarma. Dalam makalah ini, penulis membahas penokohan dalam Kitab Omong Kosong. Dalam novel ini, pengarang mengubah pola cerita. Tokoh sentral dalam cerita ini bukan lagi Rama dan Sinta, tetapi Maneka dan Satya. Ceritanya bukan lagi kisah cinta Rama dan Sinta, tetapi kisah perjalanan Maneka dan Satya dalam mencari Kitab Omong Kosong ciptaan Hanoman. Tokoh Rama tidak lagi diceritakan sebagai kesatria yang baik, tetapi sebagai raja yang membawa bencana bagi rakyat di muka bumi.
\end{abstract}

Kata kunci: penokohan, Ramayana, Kitab Omong Kosong,

\begin{abstract}
Generally, the prominent thing in a puppet show is the characters of the show. The characters are related to the lakon of the story. According to that, when people are watching a puppet show, actually they are watching the performance of of the lakon. Lot of puppet stories are adapted into prose, poem, or modern drama. One of the creation which adapt the story of Ramayana is Kitab Omong Kosong by Seno Gumira Ajidarma. In this research, the writer examined the characterization in Kitab Omong Kosong. In this novel, the writer of the book changed the plot of the story. The central characters of the story are Maneka and Satya instead of Rama and Sinta. The story is not about the love story of Rama and Sinta, but the journey of Maneka and Satya searching for Kitab Omong Kosong created by Hanoman. The character of Rama is not the knight with a good behavior, but as the king who brought disaster to the people on earth.
\end{abstract}

Keywords: characterization, Ramayana, Kitab Omong Kosong,

\section{PENDAHULUAN}

\subsection{Latar Belakang}

Kebudayaan merupakan unsur penting dalam proses pembangunan bangsa. Kata kebudayaan berasal dari kata buddhayah yang merupakan bentuk jamak dari kata buddhi yang berarti 'budi' atau 'akal'. Oleh karena itu, kata kebudayaan dapat diartikan sebagai hal-hal yang berkaitan dengan dengan budi dan akal (Koentjaraningrat, 1984:9). Menurut
Koentjaraningrat, kebudayaan mengandung tujuh unsur yang disebut cultural universal (unsur-unsur kebudayaan yang universal), yaitu sistem religi dan upacara keagamaan, sistem dan organisasi kemasyarakatan, sistem pengetahuan, bahasa, kesenian, sistem mata pencaharian hidup, serta sistem teknologi dan peralatan (Koentjaraningrat, 1984:2).

Wayang sebagai bagian dari kesenian daerah di Nusantara dapat dikatakan sebagai salah satu puncak 
Prima Hariyanto: Penokohan dalam Kitab Omong Kosong Karya Seno Gumira Ajidarma

kebudayaan Indonesia. Kata wayang berasal dari kata dalam bahasa Jawa yang berarti 'bayangan', sedangkan dalam bahasa Melayu berarti 'bayangan', 'samar-samar', 'remang-remang', atau 'menerawang'. Oleh karena itu, wayang kulit tersebut menghasilkan bayangan atau wayangan sehingga disebut wayang (Hazeu, 1979: 50-51).

Kesenian wayang dalam bentuknya yang asli timbul sebelum kebudayaan Hindu masuk di Indonesia dan mulai berkembang pada zaman Hindu Jawa. Pertunjukan kesenian wayang merupakan sisasisa upacara keagamaan orang Jawa yaitu sisa-sisa kepercayaan animisme dan dinamisme. Asal-usul kesenian wayang hingga kini masih menjadi perdebatan. Menurut Kitab Centini, wayang purwa mula-mula diciptakan oleh Raja Jayabaya dari Kerajaan Mamenang/Kediri. Sekitar abad X, Raja Jayabaya berusaha menciptakan gambaran dari roh leluhurnya yang digoreskan di atas daun lontar. Bentuk gambaran wayang tersebut ditiru dari gambaran relief cerita Ramayana pada Candi Penataran di Blitar. Cerita Ramayana sangat menarik perhatiannya karena Jayabaya termasuk penyembah Dewa Wisnu yang setia. Bahkan, ia dianggap sebagai penjelmaan atau titisan Batara Wisnu oleh masyarakat. Figur tokoh yang digambarkan untuk pertama kali adalah Batara Guru atau Sang Hyang Jagadnata, yaitu perwujudan dari Dewa Wisnu.

Jenis wayang di Nusantara cukup beragam, di antaranya wayang kulit purwa, wayang orang, wayang madya, wayang gedong, wayang golek, dan sebagainya. Cerita wayang, terutama wayang kulit purwa, diambil dari cerita wayang yang diadaptasi dari cerita Mahabarata dan Ramayana di India.

Ramayana merupakan sebuah kisah klasik yang dikenal sepanjang masa, bersama dengan Mahabarata. Kisah Ramayana ini merupakan salah satu kitab suci agama Hindu di India yang memiliki beberapa dimensi yang bersifat filosofis. Naskah ini semula berbentuk syair yang disebut Purana kemudian disusun kembali oleh seorang pujangga India bernama Walmiki dalam bahasa Tamil, yaitu bahasa salah satu suku kuno di India (Hakim, 2009). Walmiki merupakan seorang adikawi (penyair utama), sedangkan Ramayana dan Mahabarata adalah syair utama dan idaman serta kawi itihasa atau syair sejarah, yaitu syair kepahlawanan dengan daya khayal tinggi yang telah menceritakan hal-hal yang seolaholah benar-benar terjadi jika mengingat kekaburan atau keraguan akibat berlalunya waktu (Lal, 2008:13).

Seiring dengan perkembangan zaman, cerita wayang banyak diadaptasi menjadi prosa, puisi, maupun drama modern. Hal ini guna memenuhi keinginan masyarakat untuk mendapatkan bacaan yang menarik dan enak dibaca. Masyarakat cenderung menganggap bacaan Ramayana dan Mahabarata sangat membosankan. Oleh karena itu, diciptakanlah bacaan kontemporer dengan mengambil cerita tersebut. Hingga kini, sudah banyak prosa dan puisi yang diilhami dari cerita wayang, baik dari cerita Ramayana maupun Mahabarata.

Salah satu karya yang mengambil cerita Ramayana adalah Kitab Omong Kosong karya Seno Gumira Ajidarma. Di dalam novel ini, pengarang mencoba mengubah pola cerita. Tokoh sentral dalam cerita ini bukan lagi Rama dan Sinta, tetapi Maneka dan Satya. Ceritanya bukan lagi kisah cinta Rama dan Sinta, tetapi kisah perjalanan Maneka dan Satya dalam mencari Kitab Omong Kosong ciptaan Hanoman. Tokoh Rama tidak lagi diceritakan sebagai kesatria yang baik, tetapi sebagai raja yang membawa bencana bagi rakyat di muka bumi. Berdasarkan hal ini, penulis akan menganalisis tokoh dan penokohan dalam Kitab Omong Kosong.

\subsection{Rumusan Masalah}

Ramayana merupakan karya sastra yang berasal dari India, bersama dengan Mahabarata. Ramayana tidak hanya dikenal di India, tetapi juga di berbagai negara, termasuk Indonesia. Di Indonesia, kisah ini berkembang menjadi beberapa karya, salah satunya kesenian wayang. Pada zaman modern sekarang, kisah ini juga berkembang menjadi prosa, salah satunya novel Kitab Omong Kosong karya Seno Gumira Ajidarma. Sebagaimana telah dijelaskan 
Prima Hariyanto: Penokohan dalam Kitab Omong Kosong Karya Seno Gumira Ajidarma

sebelumnya, pusat kisahan dalam novel ini berbeda dengan kisah aslinya. Oleh karena itu, dalam makalah ini dibahas tokoh dan penokohan dalam Kitab Omong Kosong karya Seno Gumira Ajidarma untuk membedakan dengan kisah aslinya.

\subsection{Tujuan}

Makalah ini membahas tokoh dan penokohan dalam Kitab Omong Kosong karya Seno Gumira Ajidarma untuk membedakan dengan kisah aslinya.

\subsection{Metode}

Dalam penelitian ini, penulis menggunakan metode kualitatif. Metode ini lebih mementingkan proses daripada hasil. Berbeda dengan metode kuantitatif, dalam analisis datanya, metode ini tidak menggunakan analisis statistik, tetapi lebih banyak secara naratif. Data kualitatif yang digunakan mencakup beberapa hal seperti

a. deskripsi yang mendetail tentang situasi, kegiatan, atau peristiwa maupun fenomena tertentu;

b. pendapat langsung dari orang-orang yang telah berpengalaman, pandangannya, sikapnya, kepercayaan, dan jalan pikirannya;

c. cuplikan dari dokumen, dokumen laporan, arsip-arsip, dan sejarahnya; dan

d. deskripsi yang mendetail tentang sikap dan tingkah laku seseorang.

Oleh karena itu, agar dapat mengumpulkan data kualitatif dengan baik, peneliti harus mengetahui apa yang harus dicari, asal muasalnya, dan hubungannya dengan yang lain, yang tidak terlepas dari konteksnya (Yusuf, 2007:53).

Dalam penelitian ini, penulis menggunakan dua model data kualitatif dari empat model yang disebutkan di atas, yaitu deskripsi yang mendetail tentang situasi, kegiatan, atau peristiwa maupun fenomena tertentu dan cuplikan dari dokumen, dokumen laporan, arsip-arsip, dan sejarahnya. Untuk model pertama, penulis mencoba menggunakannya dalam mendeskripsikan fenomena tertentu yang unik, yaitu fenomena pengubahan penokohan dari kisah Ramayana menjadi cerita dalam Kitab Omong Kosong. Untuk model kedua, penulis mencuplik data penelitian dari dokumen dan arsip-arsip, yaitu novel Kitab Omong Kosongdan beberapa buku dan sumber yang menunjang penelitian ini.

\section{LANDASAN TEORI}

Pada umumnya, hal yang menonjol dalam wayang adalah tokoh-tokohnya. Karakter tokoh berkaitan dengan lakon dalam kisah tersebut. Oleh karena itu, jika orang melihat sebuah pertunjukan wayang, sebenarnya yang dilihat adalah pertunjukan lakon. Dengan demikian kedudukan lakon di dalam pakeliran sangat vital sifatnya. Melalui garapanlakon akan terungkap nilai-nilai kemanusiaan yang dapat memperkaya pengalaman kejiwaan (Murtiyoso, dkk., 2004:56).

Lakon merupakan salah satu kosakata bahasa Jawa. Lakon berasal dari kata laku yang artinya 'perjalanan, cerita, atau rentetan peristiwa'. Jadi, lakon wayang adalah perjalanan cerita wayang atau rentetan peristiwa wayang. Perjalanan cerita wayang ini berhubungan erat dengan tokoh-tokoh yang ditampilkan (Murtiyoso, dkk., 2004:57).

Tokoh merupakan individu rekaan yang mengalami peristiwa atau berlakuan dalam berbagai peristiwa dalam cerita (Sudjiman, 1986:80). Tokoh utama adalah tokoh yang diutamakan penceritaannya dalam novel yang bersangkutan. Ia merupakan tokoh yang paling banyak diceritakan, baik sebagai pelaku kejadian maupun yang dikenai kejadian (Nurgiyantoro, 2005:176).

Dalam kisah Ramayana,yang bertindak sebagai tokoh utama adalah Rama dan Sinta, sedangkan Lesmana merupakan tokoh utama tambahan. Klasifikasi ini merujuk pada pernyataan Burhan Nurgiyanto, yaitu pembedaan tokoh itu bersifat gradasi, kadar keutamaan tokoh bertingkat: tokoh utama (yang) utama, utama tambahan, tokoh tambahan utama, tambahan (yang memang) tambahan. Ketiga tokoh di atas merupakan tokoh 
protagonis, sedangkan tokoh antagonisnya adalah Rahwana.

Karena tokoh-tokoh tersebut merupakan rekaan pengarang, pengaranglah yang 'mengenal' mereka. Oleh karena itu, tokoh-tokoh itu perlu digambarkan ciri-ciri lahir dan sifat serta sikap batinnya agar wataknya dikenal oleh pembaca. Watak ialah kualitas tokoh dan penciptaan citra tokoh inilah yang disebut penokohan. Penyajian watak tokoh dan penciptaan citra tokoh ini yang disebut penokohan (Sudjiman, 1988:23).

Sebuah karya juga tak lepas dari latar belakang pengarangnya yang memengaruhi karya yang dihasilkan. Kitab Omong Kosong lahir dari salah seorang sastrawan produktif Indonesia, yakni Seno Gumira Ajidarma. Ia lahir di Boston, 19 Juni 1958 dan hingga kini telah menghasilkan banyak karya, baik cerita pendek, novel, puisi, maupun esai. Seno adalah anak dari Prof. Dr. MSA Sastroamidjojo, guru besar Fakultas MIPA Universitas Gadjah Mada. Seno adalah sosok anak pembangkang. Ia sering sekali melanggar aturan sekolah. Ketika masa sekolah, dalam kesehariannya, ia jarang bergaul dengan temanteman di sekitar rumahnya di kompleks rumah dosen UGM. Ia malah bergaul dengan anak-anak berandal di lingkungan kumuh yang sering tawuran dan ngebut di Malioboro. Dari latar belakang inilah mungkin salah satu karyanya juga "membangkang" dari cerita aslinya.

Pada usia 19 tahun, Seno menikah. Tuntutan keuangan membuatnya harus bekerja. Ia pun menjadi wartawan dan fotografer. Sejak itulah tulisantulisannya banyak dimuat di media massa. Tulisantulisannya banyak berisi kritikan terhadap pemerintah. Bahkan, ia pernah dipecat dari pekerjaannya karena tulisannya. Pada masa Orde Baru, ketika dunia pers berada di bawah kendali pemerintah, Seno menyampaikan pikiran-pikirannya melalui karya sastra, terutama cerita pendek yang dimuat di media cetak. Sering kali cerpennya ditolak oleh redaktur dengan alasan terlalu mengkritik pemerintah atau menguak peristiwa yang ditabukan untuk dibicarakan oleh pemerintah.

Pada tahun 1987, Seno mendapat Sea Write Award. Cerpen "Saksi Mata" juga membawa Seno memperoleh Dinny O'Hearn Prize for Literary pada tahun 1997. Pada tahun 2005, ia juga meraih Khatulistiwa Literary Award. Dalam dunia fiksinya, Seno sering menggunakan nama tokoh yang sama, yaitu Sukab. Menurutnya, melalui tokoh Sukab, ia dapat menyalurkan pikiran-pikirannya kepada pembaca meskipun tokoh Sukab adalah nama yang taksengaja ia temukan dan selalu saja muncul dalam pikirannya ketika ia menulis cerita.

Pada tahun 2005, Seno telah menyelesaikan program doktoralnya di Jurusan Sastra, Universitas Indonesia. Kesibukannya sekarang adalah membaca, menulis, memotret, jalan-jalan, membuat komik, dan bergelut dalam dunia teater. Seno bekerja di Pusat Dokumentasi Jakarta-Jakarta.

\section{HASIL DAN PEMBAHASAN}

\subsection{Kitab Omong Kosong Karya Seno Gumira} Ajidarma

Kitab Omong Kosong merupakan novel karya Seno Gumira Ajidarma yang diterbitkan tahun 2004. Cerita dalam novel ini bersumber dari epos Ramayana yang cukup terkenal di Indonesia. Pengarang mencoba menggubah dan membalikkan cerita dan tokoh Ramayana dalam novel ini. Berikut ini adalah ringkasan cerita Kitab Omong Kosong.

Rahwana tidak musnah meskipun dikalahkan Rama sehingga ia membalas dendam dengan menebar benih-benih kejahatan di muka bumi. Banyak orang yang yang menjadi korban Rahwana, termasuk Rama. Rama menuduh Sinta berselingkuh dengan Rahwana selama ia ditawan oleh Rahwana. Karena tuduhan tersebut, Sinta pergi dari Ayodya. Sepeninggalan Sinta dari Ayodya, Rama tidak pergi mencarinya. Oleh karena itu, Rama pun melaksanakan upacara Persembahan Kuda untuk menebus kesalahannya. Upacara tersebut juga ditujukan untuk menaklukkan anak benua. Kuda yang digunakan untuk upacara 
tersebut adalah kuda putih yang disemati daun emas di kepalanya. Akan tetapi, upacara tersebut justru membuahkan kekacauan yang luar biasa. Semua daerah yang dilewati oleh kuda tersebut mengalami kerusakan yang cukup parah. Melihat kekacauan yang terjadi, Lawa dan Kusa, anak Sinta menangkap kuda putih tersebut.

Setelah ditangkap, kuda tersebut dijadikan rajah di punggung seorang pelacur bernama, Maneka. Sejak adanya rajah kuda putih di punggungnya, Maneka banyak diminati oleh semua orang. Baik laki-laki maupun perempuan, tua maupun muda ingin tidur dengannya. Maneka pun keletihan dan menganggap bahwa rajah tersebut membawa bencana baginya. Oleh karena itu, ia pun pergi menemui Walmiki. Dalam perjalanannya menemui Walmiki, ia bertemu dengan Satya yang kemudian menemaninya mencari Walmiki. Maneka dan Satya memiliki tujuan yang sama, yaitu ingin menanyakan mengapa mereka dimasukkan ke dalam cerita Ramayana. Dalam perjalanan tersebut, mereka juga ditemani oleh Sapi Benggala.

Perjalanan Maneka dan Satya mengikuti arah matahari terbenam. Di tengah perjalanan, seseorang memanahkan peta ke pedati mereka. Peta tersebut adalah peta keberadaan Kitab Omong Kosong. Kitab karya Hanoman yang berisi kisah peradaban manusia tersebut dapat membantu manusia menghemat waktu 300 tahun untuk membangun kembali peradaban yang hancur akibat upacara Persembahan Kuda. Akhirnya, Maneka dan Satya membatalkan niat mereka mencari Walmiki. Mereka pun pergi mencari Kitab Omong Kosong. Dalam perjalanan meraka ke arah selatan, mereka diganggu oleh sekte dari Gurun Thar. Sekte tersebut menangkap Maneka untuk dijadikan persembahan kepada dewa. Hanoman yang melihat penderitaan Maneka pun terbangun dari tapanya dan menolong Maneka.

Sejak penangkapan Maneka tersebut, Satya dan Maneka terpisah. Setelah Maneka ditolong oleh Hanoman, ia melanjutkan perjalanan. Di pinggir danau dekat pertapaan Hanoman, Maneka bertemu dengan Walmiki. Ketika mencari Maneka, Satya juga bertemu dengan Walmiki di sebuah kedai. Setelah keduanya bertemu dengan Walmiki, mereka pun bersatu kembali dan melanjutkan perjalanan mereka mencari Kitab Omong Kosong. Dalam perjalanan tersebut, mereka juga menamui Hanoman di Goa Kendalisada dan menanyakan asal-usul kitab tersebut. Setelah bercerita panjang lebar, Hanoman pergi dan meminta Maneka dan Satya beristirahat di goa tersebut. Akhirnya, Kitab Omong Kosong pun ditemukan secara tidak sengaja bersamaan dengan meninggalnya Hanoman.

\subsection{Penohohan dalam Kitab Omong Kosong}

Berbeda dengan cerita Ramayana yang tokoh utamanya adalah Rama dan Sinta, dalam Kitab Omong Kosong yang bertindak sebagai tokoh utama adalah Maneka dan Satya serta Rama. Klasifikasi ini merujuk pada pernyataan Burhan Nurgiyanto, yaitu pembedaan tokoh itu bersifat gradasi, kadar keutamaan tokoh bertingkat: tokoh utama (yang) utama, utama tambahan, tokoh tambahan utama, tambahan (yang memang) tambahan.

Karena tokoh-tokoh tersebut merupakan rekaan pengarang, pengaranglah yang 'mengenal' mereka. Oleh karena itu, tokoh-tokoh itu perlu digambarkan ciri-ciri lahir dan sifat serta sikap batinnya agar wataknya dikenal oleh pembaca. Watak ialah kualitas tokoh dan penciptaan citra tokoh inilah yang disebut penokohan. Penyajian watak tokoh dan penciptaan citra tokoh ini yang disebut penokohan (Sudjiman, 1988: 23).

Dalam makalah ini, penulis membahas penokohan dari ketiga tokoh utama di atas, yaitu Maneka, Satya, dan Rama. Menurut penulis, tokoh utama yang menjadi pokok penceritaan adalah Maneka dan Satya karena pengarang menceritakan ketiganya secara panjang lebar dalam mencari Kitab Omong Kosong. Hal ini dapat dilihat dari struktur penceritaan pengarang. Kitab Omong Kosong dibagi menjadi tiga bagian. Bagian pertama menceritakan Rama dan upacara Persembahan Kuda, sedangkan bagian kedua dan ketiga menceritakan kisah perjalanan Maneka dan 
Prima Hariyanto: Penokohan dalam Kitab Omong Kosong Karya Seno Gumira Ajidarma

Satya mencari Kitab Omong Kosong. Rama merupakan tokoh utama yang menjadi penyebab segala peristiwa yang terjadi di dalam novel ini. Peristiwa yang menjadi penyebab utama konflik novel ini tak lain adalah upacara Persembahan Kuda.

\section{a. Maneka}

Maneka merupakan salah satu korban upacara Persembahan Kuda yang menghancurleburkan seluruh negeri yang dilewati kuda putih. Ketika Lawa dan Kusa berhasil menangkap kuda putih tersebut, kuda tersebut dijadikan rajah di punggung Maneka. Pada awalnya, keuntunganlah yang diperoleh Maneka ketika memperoleh rajah tersebut, yaitu dirinya sebagai pelacur yang laris manis. Akan tetapi, karena terlalu larisnya, ia pun sangat letih dan taksanggup lagi melayani tamu-tamunya yang datang dari seluruh penjuru negeri, baik laki-laki maupun perempuan, tua maupun muda. Maneka juga digambarkan sebagai seorang pelacur yang sangat cantik dan selalu menarik para lelaki. Akan tetapi di balik kecantikannya, ia adalah seorang yang tidak berpendidikan dan tidak memiliki pengalaman.

Sebagai seorang yang tidak berpendidikan, Maneka merupakan orang yang cukup pandai dalam mengambil pengalaman hidupnya. Ketika ia gagal dengan niat besarnya melakukan perjalanan mencari Walmiki, ia tidak menyesal tidak dapat memperoleh informasi mengenai nasib buruk yang menimpanya, yaitu rajah kuda putih. Akan tetapi, ia malah berbangga hati karena telah mengalami perjalanan yang panjang dan menakjubkan. Ia merasa bahwa jika dirinya meneruskan perjalanan mencari Walmiki, ia takakan memperoleh pangalaman tersebut. Pengalaman penculikan sekte Gurun Thar dan pencarian Kitab Omong Kosong adalah pengalaman yang sangat berharga darinya.

Ia juga seorang yang pemberani. Hal ini dapat dilihat dari keinginan kuatnya yang untuk melarikan diri dari rumah bordil. Pelarian itu tentu saja membawa banyak dampak jelek bagi dirinya. Ia tidak lagi mempunyai penghasilan dan tentu saja akan diburu-buru oleh pengelola rumah bordil tempat ia bekerja.

\section{b. Satya}

Satya merupakan seorang pemuda berusia 16 tahun yang mengikuti perjalanan Maneka mencari Walmiki. Satya bertemu dengan Maneka ketika Maneka berhasil meloloskan diri dari rumah bordil. Satya jatuh cinta kepada Maneka sehingga ia memutuskan untuk mengikuti Maneka. Selain itu, ia juga memiliki keinginan untuk lepas dari dunia perbudakan yang mengungkungnya.

Berkebalikan dengan Maneka, Satya adalah seorang yang yang pandai dan memiliki banyak pengetahuan. Ia pandai menulis, membaca, menanam, bersajak, dan berdagang. Ia juga digambarkan sebagai seorang yang terampil dalam bekerja. Sebagai seorang budak, ia adalah seorang pekerja keras. Ia takpernah mengeluh dengan pekerjaannya. Akan tetapi, ketika bertemu dengan Maneka, Satya memiliki keberanian untuk melarikan diri dari dunia perbudakan.

\section{c. Rama}

Dalam Kitab Omong Kosong, Rama tidak lagi digambarkam sebagai seorang ksatria yang baik seperti dalam epos Ramayana dari India. Akan tetapi, dalam novel ini, Rama digambarkan sebagai sosok yang menakutkan.

Rama adalah penyebab utama kekacauan yang terjadi di muka bumi. Hal ini terjadi karena keegoisannya yang ingin menguasai seluruh benua di muka bumi. Akan tetapi, Rama bersilat lidah bahwa upacara Parsembahan Kuda ditujukan untuk menebus dosanya kepada Sinta.

Akan tetapi, setelah dilihat lebih jauh, Rama tidak pernah berniat menebus dosanya kepada Sinta. Hal ini dapat dilihat ketika ia menghadapi anaknya, Lawa dan Kusa. Ia tidak mencoba memberikan kasih sayang kepada kedua anaknya. Bahkan, ia mengutus Laksmana untuk menghadapi Lawa dan Kusa dengan kesaktiannya. Oleh karena itu, dapat dikatakan bahwa niatnya untuk menebus dosa pada Sinta gagal. Justru niat sucinya dinodai dengan hasratnya untuk 
Prima Hariyanto: Penokohan dalam Kitab Omong Kosong Karya Seno Gumira Ajidarma

menguasai dunia sehingga bukan kebaikan yang menyebar di muka bumi, melainkan kekacauan dan angkara murka.

\section{SIMPULAN}

Kitab Omong Kosong merupakan novel karya Seno Gumira Ajidarma. Cerita dalam novel ini bersumber dari epos Ramayana yang cukup terkenal di Indonesia. Dalam Kitab Omong Kosong,yang bertindak sebagai tokoh utama adalah Maneka dan Satya serta Rama. Tokoh sentral dalam novel ini tidak lagi Rama dan Sinta, melainkan Maneka dan Satya. Dalam novel ini, yang menjadi pokok penceritaan adalah upacara Persembahan Kuda dan pencarian Kitab Omong Kosong oleh Maneka dan Satya. Rama juga tidak lagi digambarkan sebagai sosok ksatria yang baik, tetapi sosok yang jahat dan menebarkan angkara murka.

\section{DAFTAR PUSTAKA}

Ajidarma, Seno Gumira. 2004. Kitab Omong Kosong. Yogyakarta: Bentang Pustaka.

Hakim, Muhamad Nur. 2008. "Ajaran Etika yang Terkandung dari Perjalanan Hidup Tokoh Rama dalam Kisah Ramayana: Telaah terhadap Buku Ramayana Karya C. Rajagopalachari,” Skripsi. Yogyakarta: UIN Sunan Kalijaga.

Hazeu, G.A.J. 1979. Kawruh Asalipun Ringgit Sastra Gegepokanipun Kaliyan Agami Ing Jaman Kina. Jakarta: Departemen Pendidikan dan Kebudayaan Penerbitan Buku dan Bacaan dan Sastra Indonesia dan Daerah.

Koentjaraningrat. 1984. Kebudayaan Mentalitas dan Pembangunan. Jakarta: PT Gramedia.

Lal, P. 2008. Ramayana. Jakarta: Pustaka Jaya.

Murtiyoso, Bambang, dkk., 2004. Pertumbuhan dan Perkembangan Seni Pertunjukan Wayang. Surakarta: Etnika.

Nurgiyantoro, Burhan. 1995. Teori Pengkajian Fiksi. Yogyakarta: Gadjah Mada University Perss.

Pendit, Nyoman S. 2009. Ramayana. Jakarta: PT Gramedia Pustaka Utama.

Rajagopalachari, C. 2008. Ramayana. Yogyakarta: IRCiSoD.

Sudjiman, Panuti. 1998. Memahami Cerita Rekaan. Jakarta: Pustaka Jaya. 
Prima Hariyanto: Penokohan dalam Kitab Omong Kosong Karya Seno Gumira Ajidarma 